\title{
Human Resources Management Practices and Affective Commitment among Financial Industry Employees in Malaysia
}

\author{
Gopal Perumal, Suguna Sinniah, Ilangovan Perumal, Zafir Khan Muhammad Makhbul, \\ Ramesh Kumar Moona Haji Mohamed
}

\begin{abstract}
Market competition increased difficulty for organizations to hold premium quality workers. This research explores on the human resources management (HRM) practices and affective commitment (AC) among a sample of 384 financial industry employees in Klang, Selangor, Malaysia. The hypotheses were developed by considering the correlation between four key HRM practices (training, career advancement, performance evaluation and rewards) and $A C$. The findings indicates that the independent variables of career development, training and performance appraisal have a positive and significant relationship with $A C$, whereas rewards has no correlation with $A C$. The findings imply that in the Malaysian financial industry needs greater training programmes and effective performance evaluations to increase employees' performance and commitment.
\end{abstract}

Keywords: Human resources management, affective commitment, Malaysian financial industry

\section{INTRODUCTION}

Competition add difficulty for firms to retain premium quality employees. Organizations generally prioritized effective human resources management (HRM) practices to become sought-after. Managers becoming greater involved in scrutinizing internal and external environments in recruitment strategies and evaluation processes. This research investigate the relationship between HRM practices and affective commitment (AC) among financial industry. Four independent variables: training, career development, performance evaluation and compensation selected for the purpose. Previous studies confirmed engaged employees loyally contribute to organizations. However, in 1990es, staff turnover saw an increased in Malaysia in lieu of job opportunity [52]. Financial services sector seen the highest turnover rates in history $(18.3 \%)$, signals the difficulty of retaining and satisfying the employees [81]. Currently, there are 27 commercial banks in Malaysia, with a total of 225,000

Revised Manuscript Received on September 22, 2019

* Correspondence Author

Gopal Perumal*, FOBAM, SEGi University, Kota Damansara, Malaysia. Email: gopalperumal@ segi.edu.my

Suguna Sinniah, FOBAM, SEGi University, Kota Damansara, Malaysia. Email: suguna@ segi.edu.my

Ilangovan Perumal, FOBAM, SEGi University, Kota Damansara, Malaysia..Email: ilangovan@ segi.edu.my

Zafir Khan Muhammad, School of Management, Faculty of Economics and Management, University Kebangsaan Malaysia. Email: zafirkhan@ukm.edu.my. Email: zafirkhan@ukm.edu.my

Ramesh Kumar Moona Haji Mohamed, UTAR University, Setapak, Malaysia.Email: rameshk@utar.edu.my employees. Findings shows demanding task with unreasonable due dates become reasons for the high turnover rate. In 2013, approximately 150 HSBC Sarawak Bank Employees' Union members quietly opposed in front of Bank Negara Malaysia as reported by [35]. This protest held because banks decrease the retrenchment benefit twice, in the name of voluntary separation scheme, and recruited of new staffs reported by [35]. The present study aims to add value by offering greater insights. Previous research has indicated that various factors, such as employee rewards, conducive work environments, equal employment opportunities, fair performance evaluation and training opportunities influence employees' commitment towards their respective organizations. Therefore, such factors will be the points of reference, in addition to the aforementioned independent variables.

\section{LITERATURE REVIEW}

\section{A. Affective Commitment}

AC defined as a multi-dimensional framework that promotes loyalty and motivates to remain in a particular organization [76] define AC as readiness of an organization to maintain correlation among staff members, which, in turn, fosters work commitment. Meanwhile, organizational justice (distributive and procedural) has proven to be significant factor for employees' obligation to an organization [88]. In addition, [62] found that controllability and affective organizational commitment are in accordance with productive work hours, perceived performance and work satisfaction. The first component of organizational commitment is AC. Dedicated workers support organization growth as they plan to progress in direction with organization [66 \& 14]. Workers attachment towards organization is necessary. Previous studies shown that committed employee's increase firm competitiveness. [98]. AC, and organizational citizenship demonstrates work commitment [85]. Moreover, [75] found that identification and internalization are positively linked to $\mathrm{AC}$, while [6] indicated that career motivation and $\mathrm{AC}$ have a positive relationship. The second component is the readiness of an employee to stay put in an organization based on social costs and expected benefit [ $68 \& 15]$. Though past studies saw relationship between job satisfaction and continuance commitment, but lack of correlation between continuance commitment and organizational cynicism. Hence, it is a benefit to revisit area of continuance 
commitment, job satisfaction and organizational cynicism [53]. Normative commitment has been defined as an employee's insistence on remaining in an organization, based on personal obligations or moral beliefs [17] such as religion, family, marriage, etc. In a study undertaken by [106], when senior officers show lower level engagement when top management engagement is low. Meanwhile, in organization, where top management engagement is higher, senior officers to saw greater engagement towards employer. Rewards refers to salaries, and incentives as well as indirect compensation including legally obligated life/health insurance and social security benefits to childcare and pensions [58 \& 89]. Overall, there are two types of compensation. First, there is basic compensation, covers contractual payments such as wages and salaries. The other is additional benefits including commission payment for exceeding individual and group output targets. Monetary reward creates establish legal contract between employers and employees [104]. Previous studies saw attractive remuneration system motivates employees and increase job performance [84], and motivating employees to fulfil employers' expectation [73]. [72] Explained rewards as job-based pay, skill-based pay and performance-based pay. Job-based pay measures the obligation in overall function, while skill-based pay measures knowledge and ability required to accomplish the job. Moreover, performance-based pay determine by the employee's productivity. [57] found reward based on skills and performance are generally appreciated by employees. Thus, a compensation system that offers reward based on external competitiveness and performance are other attractive measures. External competitiveness refers to rewarding workers with salary and fringe benefits for employees directly measurable physical productivity level [54], while reward based on performance refers to benefits based on quality of work towards overall completion of job [31]. Past literatures concluded that there are interrelation between salaries, bonuses, merit pay and organizational commitment. Moreover, previous studies also shown that greater remuneration motivates greater production, and vice versa [5, $10 \& 50]$. Therefore, it is important to establish effective reward strategies in order to improve employees' productivity as a whole.

\section{B. Training}

Past researches established that employees work quality is foundation for corporate competitiveness. Therefore HR policies aimed at attract, retain and train skilled workers. Training has been defined as a planned activity that efficiently develop employees' knowledge and skills for organizational success [94, 95, $99 \& 100]$ and improving customer service quality [99]. Training and development found to reduce employees' intentions to leave employers [61]. Research conducted by [2] saw conformity between training and job satisfaction, productivity and service quality, while [88] found training increase individual competency and increase firm performance [80]. According to [25], managerial commitment and worker training are dynamic strategies of new-age HR., which refers to management based on reliable decision-making information. Subsequently, [18] disclosed that training ultimately add value to organization based innovation strategies. While [4] found that transformational training programs strengthen employee loyalty. Moreover, motivation, access and benefits in regard to training have a significant effect on workers engagement [4]. In general, training considered a content-based activity that a trainer targeting to transform the attitudes of workers in order to fulfil management goals [23]. Training, including orientation training, physical training, on-the-job training, off-the-job training, remedial training, refresher training, in-house training, external training etc. [4]. Training expected to transform workers be competent, training too fulfils the firm's vision, mission, goals and objectives [87 \& 82]. Older employees also required to retrain and up train in order to remain competitive in the presentence of younger counterparts. Organization's priority should provide necessary skills training to increase efficiency, to uphold organizational goals and aims over the long term [28]. In other hand, there are researches discover that training is less benefit in supplementing talents required by company [43]. Thus, numerous studies have focused on ways to improve quality of training in order to develop knowledge and skills in the workplace [11, 39, 41, $45 \& 92]$.

\section{Career Advancement}

Career advancement, which is a technique utilize by organizations to foster workers career paths, has been conceptualized into four areas: professional capacity improvement, occupation goal growth, compensation development and promotion [93 \& 105]. Career advancement builds a strong bonding between employees and organizations. Previous studies found less satisfied employees chooses to resign and join competing organizations. Likewise, career satisfaction increase loyalty towards organization [65]. Hence, career advancement significantly support organizational growth.

Career advancement strategies include activities that fulfills employees' interests as well as for immediate, short, medium- and long-term goals of the organization [75]. Such initiatives certainly support convergence between career-related programs, job satisfaction and commitment [46]. According to [24] career advancement expands employees' skills and empowers them to integrate their knowledge into the tasks at hand, while [27] found that an effective career advancement program potentially leads to higher productivity and better work performance. In addition, it reduces staff turnover rates as workers happy with their jobs and duties. Despite such positive aspects, career advancement has received limited devotion by many employers. Thus, more organizations, regardless of their reputation of minimizing work-related stress, need to be aware of the importance of career advancement among their employees [12 \& 44]. Career advancement is also related to employees' positions and the needs of their respective organizations. In this regard, the Career Growth Scale can be a valid instrument for measuring career growth, since it incorporates an employee's cultural background into corporate advancement. Meanwhile, the whole-life viewpoint on career advancement recognizes that workers ultimately aim to develop their careers, while 
maintaining a healthy work-life balance [51]. However, although the career-related literature has emphasized inter-organizational movement as a means to realizing the aim, whole-life career advancement possible to accomplish within an organization, provided management address workers work-family needs [59]. Finally, [102] found that involved, high-performing employees tend to have positive attitudes towards work as they aware of the dynamics of workplace. Moreover, they tend to serve as models for their subordinates. Thus, there is a significant relationship between characteristics of high-performing employees and subordinates [60].

\section{Performance Evaluation}

As per [77, 16, $56 \& 71]$, performance evaluation is a measure of workers expected performance against actual performance in a financial year. During the process, feedback is provided for improvements and required training is proposed [71]

[71] Defines performance evaluation has three types: administrative, informative and motivational. The administrative focuses on an employee's promotions and salary rises, whereas the informative provides evidence and statistics worker's performance, which is especially helpful for those in management [56]. Moreover, the motivational approach focuses on an employee's personal development and motivation through learning experiences. Performance evaluation serve as a tool for employees to demonstrate their value and work towards achieving organizations expectation. It is worth noting that such appraisals are provided to all employees, regardless of their work attitudes, the outcomes can differ. An aggressive worker usually become less motivated when their work performance falls below certain key levels, whereas mediocre worker adopt aggressive approaches in order to impress their employers [38]. Employers apply two types of workers performance evaluation: official (systematic) and unofficial (non-systematic). [90] Explained unofficial appraisals include the supervision and evaluation of employees by their employers. In regard to formal appraisals, [32] stated that in official methods, employers evaluate employees' expected performance and against actual performance. Performance evaluation also linked to financial rewards, which greatly motivate employees. The consequences can be detrimental for open-minded and self-determined employees the appraisal outcome falls below expected financial rewards [49]. Conversely, employees' work satisfaction and motivation can be increased if organizations clearly state whether monetary awards will be provided, based on periodic performance evaluation. Finally, the perception of fairness in such appraisals is still debatable [34]. Performance evaluation s negative influence on employees' work performance when employees believe unfairly appraised. [101]. [22] argues such perceptions are based on beliefs beyond unreasonable expectation [22]. As the performance evaluations are subjective, employers should practice transparent and effective communication to exercise fairness in leader-member exchange and leader-member exchange to boost motivation and performance improvement [97].

\section{METHODOLOGY}

\section{A. Sample and data collection}

The respondents for this study sourced from 27 major financial companies in Klang, Selangor, Malaysia. According to [37] proposed that a sample size of 300 is sufficient for structural equation modelling (SEM). A total of 800 self-reported surveys were distributed and 384 completed responses were received and applied in the SEM analysis. The data used in the study obtained from questionnaires adapted from past literature.

\section{B. Measures}

The self-reported surveys consisted of 45 items based on a five-point Likert scale ranging from 1 (strongly disagree) to 5 (strongly agree). The data initially analyzed through SPSS statistical software (version 22) to deportment a descriptive analysis and to term the validity and reliability of the data. Next, Smart PLS 3.0 software was used to perform the SEM analysis and to test the hypotheses. The findings of the convergent and discriminant validity assessments are presented in Tables 1 and 2, respectively. As for the reliability of the data, all of the Cronbach's alpha coefficients stood above 0.7 , denotes a high level of internal consistency [83]. In the present study, the Cronbach's alpha coefficients stood 0.959 for compensation, 0.933 for training, 0.844 for career advancement and 0.882 for organizational commitment

\section{RESULTS AND DISCUSSION}

The hypotheses were established by using SEM estimation. [91], Smart PLS 3.0 software was applied to analyse the data and conclude the significance levels for the factor loadings, weights and path coefficients.

In addition, based on the two-stage analytical procedures by [3], the validity and goodness of the measurement model was tested, followed by an examination of the relationships outlined in the structural model.

\section{A. Measurement model and structural model estimation}

First test was conducted for reliability, convergent validity and discriminant validity. Figure 1 presents the scores for the measurement model. As shown in Table 1, all of the factor loadings are higher than 0.70 [37], and the average variance extracted (AVE) of all of the constructs exceeds 0.5 [13]. Moreover, the composite reliability (CR) scores were higher than 0.6 [37]. Based on these results, it is possible to determine that convergent validity was achieved. Table 2 displays the results of the discriminant validity check. [29 \& 30] and, proposed that the AVE of each construct should be higher than the correlation between the other constructs in the model. All the constructs in the study met this criterion and holds discriminant validity. Table 3 displays heterotrait-monotrait (HTMT) values are not greater than the .85 value of [54] or the .90 value of Gold and [60]. In addition, as shown in Table 4 . It is possible to conclude that discriminant validity was 
Human Resources Management Practices and Affective Commitment among Financial Industry Employees in Malaysia

achieved as the cross loadings of all constructs under review satisfied. Finally, Table 5 and Figure 2 shows results of the hypotheses tests and the final structural model, respectively.

Figure 1 Measurement model

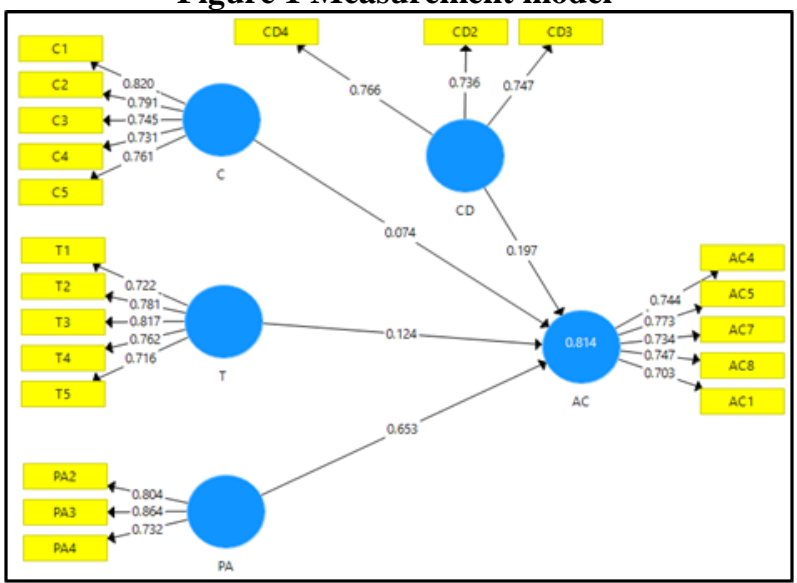

\begin{tabular}{|l|c|c|c|c|c|c|}
\hline Items & Loadings & Cronbach's Alpha & rho_A & CR & AVE & VIF \\
\hline AC1 & 0.703 & 0.799 & 0.813 & 0.86 & 0.55 & 1.59 \\
\hline AC4 & 0.744 & & & & & 1.441 \\
\hline AC5 & 0.773 & & & & 1.487 \\
\hline AC7 & 0.734 & & & & & 1.79 \\
\hline AC8 & 0.747 & & & & & 1.8 \\
\hline C1 & 0.82 & 0.828 & 0.831 & 0.88 & 0.59 & 1.972 \\
\hline C2 & 0.791 & & & & & 1.8 \\
\hline C3 & 0.745 & & & & & 1.63 \\
\hline C4 & 0.731 & & & & & 1.486 \\
\hline C5 & 0.761 & & & & & 1.662 \\
\hline CD2 & 0.736 & 0.622 & 0.626 & 0.79 & 0.56 & 1.348 \\
\hline CD3 & 0.747 & & & & & 1.387 \\
\hline CD4 & 0.766 & & & & & 1.123 \\
\hline PA2 & 0.804 & 0.726 & 0.75 & 0.84 & 0.64 & 1.363 \\
\hline PA3 & 0.864 & & & & & 1.644 \\
\hline PA4 & 0.732 & & & & & 1.427 \\
\hline T1 & 0.722 & 0.817 & 0.821 & 0.87 & 0.58 & 1.474 \\
\hline T2 & 0.781 & & & & & 1.661 \\
\hline T3 & 0.817 & & & & \\
\hline T4 & 0.762 & & & & & 1.931 \\
\hline T5 & 0.716 & & & & 1.593 \\
\hline & & & & & 1.517 \\
\hline & & & & & \\
\hline
\end{tabular}

Table 1 Convergent validity

\begin{tabular}{cccccc} 
& AC & C & CD & PA & T \\
\hline AC & $\mathbf{0 . 7 4}$ & & & & \\
& 0.65 & $\mathbf{0 . 7 7}$ & & & \\
C & 1 & $\mathbf{1}$ & & & \\
& 0.61 & & & & \\
CD & 5 & 0.45 & $\mathbf{0 . 7 5}$ & & \\
& 0.86 & 0.60 & 0.47 & $\mathbf{0 . 8 0}$ & \\
PA & 2 & 7 & 8 & $\mathbf{2}$ & \\
& 0.65 & 0.73 & 0.58 & 0.55 & $\mathbf{0 . 7 6}$ \\
T & 8 & 8 & 5 & 7 & $\mathbf{1}$ \\
\hline \multicolumn{5}{c}{ Table 2 } & Discriminant validity
\end{tabular}

Table 3 HTMT

\begin{tabular}{|c|c|c|c|c|c|c|}
\hline & $\mathrm{AC}$ & $\mathrm{C}$ & $\mathrm{CD}$ & PA & $\mathrm{T}$ & $\begin{array}{l}\text { Saturated } \\
\text { Model }\end{array}$ \\
\hline $\mathrm{AC}$ & 0.79 & & & & SRMR & 0.068 \\
\hline $\mathrm{C}$ & $\begin{array}{r}2 \\
0.63\end{array}$ & 0.49 & & & d_ULS & 0.629 \\
\hline $\mathrm{CD}$ & $\begin{array}{r}1 \\
0.55\end{array}$ & 4 & 0.30 & & d_G1 & 0.271 \\
\hline PA & $\begin{array}{r}3 \\
0.78\end{array}$ & $\begin{array}{l}0.52 \\
0.82\end{array}$ & $\begin{array}{r}6 \\
0.71\end{array}$ & 0.3 & d_G2 & 0.256 \\
\hline $\mathrm{T}$ & 1 & 8 & 9 & 7 & Chi-square & 554.263 \\
\hline
\end{tabular}

Table 4 Cross loadings

\begin{tabular}{|c|c|c|c|c|c|}
\hline Items & $\mathrm{AC}$ & $\mathrm{C}$ & $\mathrm{CD}$ & PA & $\mathrm{T}$ \\
\hline & 0.70 & 0.44 & 0.53 & 0.42 & 0.44 \\
\hline \multirow[t]{2}{*}{$\mathrm{AC} 1$} & 3 & 8 & 9 & 8 & 2 \\
\hline & 0.74 & 0.51 & & 0.80 & 0.46 \\
\hline \multirow[t]{2}{*}{$\mathrm{AC} 4$} & 4 & 1 & 0.37 & 4 & 2 \\
\hline & 0.77 & 0.48 & 0.46 & 0.86 & 0.49 \\
\hline \multirow[t]{2}{*}{ AC5 } & 3 & 4 & 1 & 4 & 5 \\
\hline & 0.73 & 0.48 & 0.46 & 0.45 & 0.51 \\
\hline \multirow[t]{2}{*}{ AC7 } & 4 & 3 & 8 & 4 & 9 \\
\hline & 0.74 & 0.48 & 0.48 & & 0.53 \\
\hline \multirow[t]{2}{*}{ AC8 } & 7 & 3 & 6 & 0.46 & 5 \\
\hline & 0.53 & & 0.36 & 0.49 & 0.58 \\
\hline \multirow[t]{2}{*}{$\mathrm{C} 1$} & 5 & 0.82 & 9 & 1 & 2 \\
\hline & 0.51 & 0.79 & 0.35 & 0.50 & 0.60 \\
\hline \multirow[t]{2}{*}{$\mathrm{C} 2$} & 1 & 1 & 8 & 1 & 6 \\
\hline & 0.45 & 0.74 & & 0.46 & 0.52 \\
\hline \multirow[t]{2}{*}{ C3 } & 3 & 5 & 0.29 & 1 & 8 \\
\hline & 0.52 & 0.73 & 0.36 & 0.44 & 0.53 \\
\hline \multirow[t]{2}{*}{$\mathrm{C} 4$} & 2 & 1 & 7 & 9 & 5 \\
\hline & 0.47 & 0.76 & & 0.43 & 0.59 \\
\hline \multirow[t]{2}{*}{ C5 } & 9 & 1 & 0.34 & 3 & 1 \\
\hline & 0.41 & 0.34 & 0.73 & 0.40 & 0.41 \\
\hline \multirow[t]{2}{*}{$\mathrm{CD} 2$} & 4 & 1 & 6 & 2 & 9 \\
\hline & 0.38 & 0.29 & 0.74 & 0.28 & 0.49 \\
\hline \multirow[t]{2}{*}{ CD3 } & 4 & 2 & 7 & 3 & 8 \\
\hline & 0.55 & 0.36 & 0.76 & 0.38 & 0.41 \\
\hline \multirow[t]{2}{*}{ CD4 } & 3 & 8 & 6 & 1 & 5 \\
\hline & 0.74 & 0.51 & & 0.80 & 0.46 \\
\hline \multirow[t]{2}{*}{ PA2 } & 4 & 1 & 0.37 & 4 & 2 \\
\hline & 0.77 & 0.48 & 0.46 & 0.86 & 0.49 \\
\hline \multirow[t]{2}{*}{ PA3 } & 3 & 4 & 1 & 4 & 5 \\
\hline & 0.51 & 0.47 & & 0.73 & 0.36 \\
\hline \multirow[t]{2}{*}{ PA4 } & 6 & 3 & 0.3 & 2 & 8 \\
\hline & 0.47 & 0.59 & 0.42 & 0.40 & 0.72 \\
\hline \multirow[t]{2}{*}{$\mathrm{T} 1$} & 4 & 3 & 7 & 6 & 2 \\
\hline & 0.53 & 0.61 & & 0.43 & 0.78 \\
\hline \multirow[t]{2}{*}{$\mathrm{T} 2$} & 7 & 3 & 0.44 & 6 & 1 \\
\hline & 0.51 & 0.55 & 0.45 & & 0.81 \\
\hline \multirow[t]{2}{*}{ T3 } & 8 & 9 & 5 & 0.46 & 7 \\
\hline & 0.51 & 0.55 & 0.48 & 0.41 & 0.76 \\
\hline \multirow[t]{2}{*}{$\mathrm{T} 4$} & 5 & 5 & 1 & 9 & 2 \\
\hline & 0.45 & 0.48 & 0.42 & 0.39 & 0.71 \\
\hline T5 & 3 & 1 & 1 & 5 & 6 \\
\hline
\end{tabular}


Table 5 Hypotheses results

\begin{tabular}{|c|c|c|c|c|c|c|c|c|c|}
\hline No. & Hypothesis & \begin{tabular}{|c|} 
Beta \\
value \\
\end{tabular} & $\begin{array}{l}\text { Std. } \\
\text { Error } \\
\end{array}$ & \begin{tabular}{|l}
$\mathrm{T}$ \\
value \\
\end{tabular} & \begin{tabular}{|l|} 
P \\
Values \\
\end{tabular} & LL & UL & $\mathrm{Q}^{2}(=1-\mathrm{SSE} / \mathrm{SSO})$ & Decision \\
\hline H1 & $\mathrm{C} \rightarrow \mathrm{AC}$ & 0.074 & 0.043 & 1.744 & 0.082 & -0.006 & 0.154 & 0.398 & Rejected \\
\hline $\mathrm{H} 2$ & $\mathrm{~T}>\mathrm{AC}$ & 0.124 & 0.048 & 2.585 & 0.01 & 0.039 & 0.225 & & Supported \\
\hline H3 & $\mathrm{CD}>\mathrm{AC}$ & 0.197 & 0.033 & 5.926 & 0 & 0.128 & 0.255 & & Supported \\
\hline $\mathrm{H} 4$ & $\mathrm{PA} \rightarrow \mathrm{AC}$ & 0.653 & 0.035 & 18.46 & 0 & 0.58 & 0.718 & & Supported \\
\hline
\end{tabular}

C: Reward, T: Training, CD: Career Advancement, PA: Performance Evaluation, AC: Affective Commitment

In order to estimate the structural model, a bootstrapping procedure with 5,000 resamples was conducted to generate the $t-$ values, based on the method of [85]. As shown in Figure 2 and Table 5, all the hypotheses were supported $(\mathrm{H} 2$ $(\beta=0.124, \mathrm{p}<0.05) ; \mathrm{H} 3(\beta=0.197, \mathrm{p}<0.05)$ and $\mathrm{H} 4(\beta=$ $0.653, \mathrm{p}<0.05))$, except for H1 $(\beta=0.074, \mathrm{p}>0.05)$.

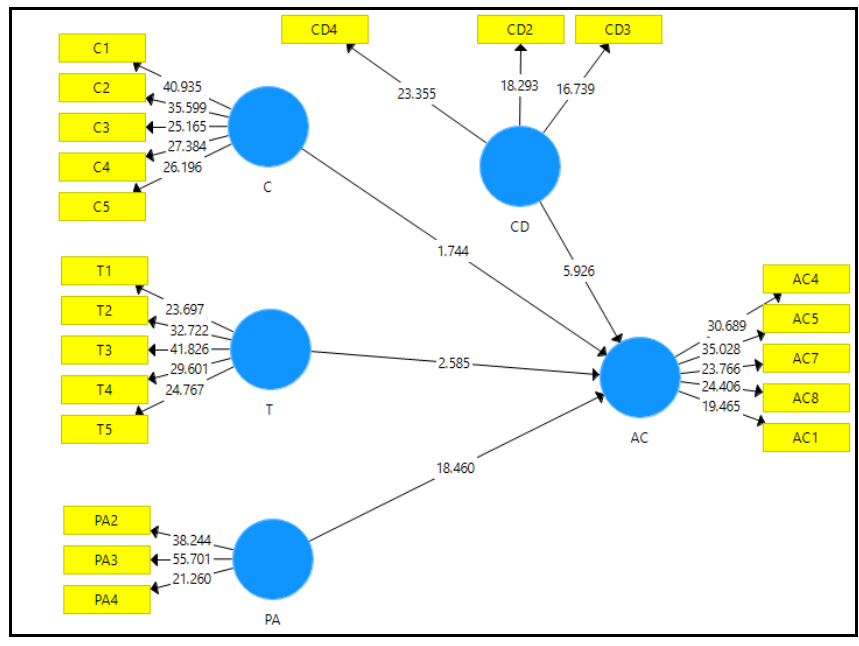

Figure 2 Final structural model

\section{CONCLUSION}

This explores the relationship between HRM practices and AC among a sample of financial industry employees in Malaysia. The hypotheses were developed by considering the relationship between four key HRM practices (reward, training, performance evaluation and career advancement) and AC. The findings, derived from SEM with partial least squares estimation and Pearson's correlation analysis, indicated the independent construct of career advancement and performance, training, and performance evaluation had a positive and significant relationship with $\mathrm{AC}$, whereas reward had no correlation with AC. The findings imply that the HR departments in the Malaysian financial industry must implement training program and offer opportunities for career advancement, which, in turn, can increase employees' work-related performance and commitment in such a way to benefit their employers and respective organizations. Finally, there is a need to revisit the performance evaluation system, since issues of fairness are still apparent. More specifically, they should ensure that such appraisals are transparent and any financial rewards are provided in an open and fair manner in order to maintain and increase employees' work motivation.

\section{REFERENCES}

1. Abd Rahman, A., Imm Ng, S., Sambasivan, M., \& Wong, F. (2013). Training and organizational effectiveness: moderating role of knowledge management process. European Journal of Training and Development, 37(5), 472-488.

2. Aboyassin, N. A., \& Sultan, M. A. (2017). The Role of Human Resources Training in Improving the Employee's Performance: Applied Study in the Five Stars Hotels in Jordan. International Journal of Business Administration, 8(5), 46.

3. Anderson, J. C., \& Gerbing, D. W. (1988). Structural equation modeling in practice: A review and recommended two-step approach. Psychological bulletin, 103(3), 411

4. Al Qudah, N. F., Yang, Y., \& Anjum, M. A. (2018). Transformational Training Programs and Quality Orientation of Employees: Does Employees' Loyalty Matter? Sustainability, 10(2), 465.

5. Alamelu, R., Surulivel, S. T., Motha, L. C. S., Amudha, R., \& Selvabaskar, S. (2015). Correlates of Employee Compensation and Commitment. Mediterranean Journal of Social Sciences, 6(5), 335

6. Alnıçık, Ü., Alnıaçık, E., Akçin, K., \& Erat, S. (2012). Relationships between career motivation, affective commitment and job satisfaction. Procedia-Social and Behavioral Sciences, 58, 355-362.

7. Appelbaum, E., Bailey, T., Berg, P. B., Kalleberg, A. L., \& Bailey, T. A. (2000). Manufacturing advantage: Why high-performance work systems pay off. Cornell University Press.

8. Asmuß, B. (2008). Performance appraisal interviews: Preference organization in assessment sequences. The Journal of Business Communication (1973), 45(4), 408-429.

9. Beson J, Zhu Y, Gospel H, editors. Employers' associations in Asia: Employer collective action. Taylor \& Francis; 2017 Jun 26.

10. Bahl, J. (2015). Impact of Employee Compensation on Firm's Performance. The International Journal of Business and Management, $3(2) 2$.

11. Baldwin, T. T., \& Ford, J. K. (1988). Transfer of training: A review and directions for future research. Personnel psychology,41(1) 63-105.

12. Baruch, Y., \& Peiperl, M. (2000). Career management practices: An empirical survey and implications. Human resource management, 39(4), 347-366.

13. Bagozzi, R. P., \& Yi, Y. (1988). On the evaluation of structural equation models. Journal of the academy of marketing science, 16(1), 74-94.

14. Becker WS. E. Appelbaum, T. Bailey, P. Berg, AL Kalleberg. Manufac.

15. Beck, K., \& Wilson, C. (2000). Development of affective organizational commitment: A cross-sequential examination of change with tenure. Journal of vocational behavior, 56(1), 114-136.

16. Boachie-Mensah, F., \& Seidu, P. A. (2012). Employees' perception of performance appraisal system: a case study. International Journal of Business and Management, 7(2), 73.

17. Bolon, M. (1993). The construct of work commitment: Testing an integrative framework. Psychological Bulletin, 131(2), 241-259.

18. Børing, P. (2017). The relationship between training and innovation activities in enterprises. International Journal of Training and Development, 21(2), 113-129.

19. Butali, P., \& Njoroge, D. (2017). Training and Development and Organizational Performance: The Moderating Effect of Organizational Commitment. International Journal of Scientific Research and Management, 5(11), 7381-7390.

20. Cambon, L., \& Yzerbyt, V. Y. (2018). Two routes toward compensation: An investigation into the mechanisms of compensation for high-and low-status groups. Journal of Experimental Social Psychology, 77, 24-35

21. Chew, J., \& Chan, C. C. (2008). Human resource practices, organizational commitment and intention to stay. International journal of manpower, 29(6), 503-522.

22. Choon, L. K., \& Embi, M. A. (2012). Subjectivity, organizational justice and performance appraisal: Understanding the concept of subjectivity in leading towards employees' perception of fairness in the performance appraisal. Procedia-Social and Behavioral Sciences, 62, 189-193.

23. Ding, Y., Zhang, G., Chambers, T., Song, M., Wang, X., \& Zhai, C. (2014). Content-based citation analysis: The next generation of citation analysis. Journal of the Association for Information Science and Technology, 65(9), 1820-1833.

24. Dressler, S. (2004). Strategy, organization and performance 


\section{Human Resources Management Practices and Affective Commitment among Financial Industry Employees in Malaysia}

management: From basics to best practices. Universal-Publishers.

25. Dubihlela, J., \& Rundora, R. (2014). Employee Training, Managerial Commitment and The Implementation of Activity Based Costing; Impact on Performance of SMEs. The International Business \& Economics Research Journal (Online), 13(1), 27.

26. Felli, L., \& Harris, C. (2018). Firm-specific training. Journal of Economic Theory, 175, 585-623.

27. Feldman, D. C., \& Weitz, B. A. (1988). Career plateaus reconsidered. Journal of Management, 14(1), 69-80.

28. Firth, L., Mellor, D. J., Moore, K. A., \& Loquet, C. (2004). How can managers reduce employee intention to quit? Journal of managerial psychology, 19(2), 170-187.

29. Fornell, C., \& Larcker, D. F. J. Cha (1994), "Partial Least Squares,". Advances Methods of Marketing Research, 52-78.

30. Fornell, C., \& Larcker, D. F. (1981). Structural equation models with unobservable variables and measurement error: Algebra and statistics.

31. Gerhart, B., \& Trevor, C. O. (1996). Employment variability under different managerial compensation systems. Academy of Management Journal, 39(6), 1692-1712.

32. Giangreco, A., Carugati, A., Sebastiano, A., \& Al Tamimi, H. (2012). War outside, ceasefire inside: An analysis of the performance appraisa system of a public hospital in a zone of conflict. Evaluation and program planning, 35(1), 161-170.

33. Gupta, V., \& Kumar, S. (2012). Impact of performance appraisal justice on employee engagement: a study of Indian professionals. Employee Relations, 35(1), 61-78.

34. Haines III, V. Y., \& St-Onge, S. (2012). Performance management effectiveness: practices or context? The International Journal of Human Resource Management, 23(6), 1158-1175.

35. Hema, S. (2015). The influence of human resource management practices and proactive personality on job performance among commercial bank employees (Doctoral dissertation, Universiti Utara Malaysia)

36. Ringle, C. M., Wende, S., \& Will, A. (2005). SmartPLS 2.0. Hamburg

37. Hair, J. F., Black, W. C., Babin, B. J., \& Anderson, R. E. (2010) Multivariate data analysis: Global edition.

38. Heywood, J. S., Jirjahn, U., \& Struewing, C. (2017). Locus of control and performance appraisal. Journal of Economic Behavior \& Organization, 142, 205-225.

39. Holton III, E. F., Bates, R. A., \& Ruona, W. E. (2000). Development of a generalized learning transfer system inventory. Human resource development quarterly, 11(4), 333.

40. Hong, E. N. C., Hao, L. Z., Kumar, R., Ramendran, C., \& Kadiresan, V. (2012). An effectiveness of human resource management practices on employee retention in institute of higher learning: A regression analysis. International journal of business research and management, 3(2), 60-79.

41. Huang, J. L., Blume, B. D., Ford, J. K., \& Baldwin, T. T. (2015). A tale of two transfers: Disentangling maximum and typical transfer and their respective predictors. Journal of Business and Psychology, 30(4), 709-732.

42. Huang, J. L., Ford, J. K., \& Ryan, A. M. (2017). Ignored no more Within-person variability enables better understanding of training transfer. Personnel Psychology, 70(3), 557-596.

43. Hutchins, H. M., Burke, L. A., \& Berthelsen, A. M. (2010). A missing link in the transfer problem? Examining how trainers learn abou training transfer. Human Resource Management, 49(4), 599-618.

44. Hu, S., Hood, M., \& Creed, P. A. (2018). Career goal importance as a moderator in the relationship between career feedback and career-related stress. Journal of Career Development, 45(1), 3-18.

45. Illeris, K. (2009). Transfer of learning in the learning society: How can the barriers between different learning spaces be surmounted, and how can the gap between learning inside and outside schools be bridged? International Journal of Lifelong Education, 28(2), 137-148.

46. Ismail, A., Adnan, N. H., Awang, A. H., Rani, N. S. A., \& Ismail, Y (2017). Interlinkages between career development, career needs, caree satisfaction and career commitment: Case study of a military-oriented tertiary educational institution in Malaysia. Geografia-Malaysian Journal of Society and Space, 11(3).

47. Islami, X., Mulolli, E., \& Mustafa, N. (2018). Using Management by Objectives as a performance appraisal tool for employee satisfaction. Future Business Journal, 4(1), 94-108

48. Illeris, K. (2009). Transfer of learning in the learning society: How can the barriers between different learning spaces be surmounted, and how can the gap between learning inside and outside schools be bridged? International Journal of Lifelong Education, 28(2), $137-148$

49. Kampkötter, P. (2017). Performance appraisals and job satisfaction. The International Journal of Human Resource Management, 28(5), 750-774.

50. Kee, L. B., bin Ahmad, R., \& Abdullah, S. M. (2016). Relationship between financial compensation and organizational commitment among Malaysian bank workers. Asian Business Research, 1(1), 75.

51. Kim, B., Rhee, E., Ha, G., Jung, S. H., Cho, D., Lee, H. K., \& Lee, S M. (2016). Cross-cultural validation of the career growth scale for Korean Employees. Journal of Career Development, 43(1), 26-36.

52. Keni, K., Muthuveloo, R., Ping, T. A., \& Rahman, R. A. (2015). Turnover intention trend among commercial banks in Penang, Malaysia. Karya Ilmiah Dosen Fakultas Ekonomi.

53. Khan, R., Naseem, A., \& Masood, S. A. (2016). Effect of continuance commitment and organizational cynicism on employee satisfaction in engineering organizations. International Journal of Innovation, Management and Technology, 7(4), 141

54. Kline, S., \& Hsieh, Y. C. J. (2007). Wage differentials in the lodging industry: A case study. Journal of Human Resources in Hospitality \& Tourism, 6(1), 69-84.

55. Kline, R. B. (2015). Principles and practice of structural equation modeling. Guilford publications.

56. Kondrasuk, J. N. (2011). So, what would an ideal performance appraisal look like? The Journal of Applied Business and Economics, 12(1), 57

57. Latif, M. S., Ahmad, M., Qasim, M., Mushtaq, M., Ferdoos, A., \& Naeem, H. (2013). Impact of employee's job satisfaction on organizational performance. European Journal of Business and Management, 5(5), 166-171.

58. Lamba, S., \& Choudhary, N. (2013). Impact of HRM practices on organizational commitment of employees. International Journal of Advancements in Research \& Technology, 2(4), 407-423.

59. Litano, M. L., \& Major, D. A. (2016). Facilitating a whole-life approach to career development: The role of organizationa leadership. Journal of Career Development, 43(1), 52-65.

60. Malhotra, P., \& Singh, M. (2016). Indirect impact of high performers on the career advancement of their subordinates. Human Resource Management Review, 26(3), 209-226.

61. Mansoor, S., Shah, F. T., ur Rehman, A., \& Tayyaba, A. (2015). Impact of Training and Development on Organization Performance with Mediating Role of Intention to Quit as Human Resource Quality Cost. European Online Journal of Natural and Social Sciences, 4(4), 787.

62. McCunn, L. J., Kim, A., \& Feracor, J. (2018). Reflections on a retrofit: Organizational commitment, perceived productivity and controllability in a building lighting project in the United States. Energy Research \& Social Science, 38, 154-164.

63. McEvoy, G. M., Cragun, J. R., \& Appleby, M. (1997). Using Outdoor Training to Develop and Accomplish Organizational Vision. Human Resource Planning, 20(3).

64. McGinley, S. P. (2018). Shifting patterns: How satisfaction alters career change intentions. International Journal of Hospitality Management.

65. McGinley, S. P., Yang, W., \& Zhang, L. (2018). Snob Appeal? Impact of Company Status Perceptions on Employee Recruitment. Journal of Hospitality Marketing \& Management, 27(1), 85-105.

66. Meyer, J. P., Stanley, D. J., Herscovitch, L., \& Topolnytsky, L. (2002) Affective, continuance, and normative commitment to the organization: A meta-analysis of antecedents, correlates, anc consequences. Journal of vocational behavior, 61(1), 20-52.

67. Mehran, H. (1995). Executive compensation structure, ownership, and firm performance. Journal of financial economics, 38(2), 163- 184

68. Meyer, J. P., \& Allen, N. J. (1991). A three-component conceptualization of organizational commitment. Human resource management review, 1(1), 61-89.

69. Meyer, J. P., \& Allen, N. J. (1997). Commitment in the Workplace: Theory, Research, and Application (Advanced Topics in Organizational Behavior). Thousand Oaks, CA: Sage Publications.

70. Meyer, J. P., Irving, P. G., \& Allen, N. J. (1998). Examination of the combined effects of work values and early work experiences on organizational commitment. Journal of organizational Behavior, 29-52.

71. McGregor, D. (1987). An uneasy look at performance appraisal. Training \& Development Journal.

72. Misra, P., Jain, S., \& Sood, A. (2013). Compensation: impact of rewards and organisational justice on turnover intentions and the role of motivation and 
job satisfaction: a study of retail store operations in NCR. International Journal of Human Resources Development and Management, 13(2-3), 136-152.

73. Mohammadi, A., Broström, A., \& Franzoni, C. (2015). Work Force Composition and Innovation: How Diversity in Employees' Ethnical and Disciplinary Backgrounds Facilitates Knowledge Re-combination (No. 413). Royal Institute of Technology, CESIS-Centre of Excellence for Science and Innovation Studies.

74. Montemayor, E. F. (1996). Congruence between pay policy and competitive strategy in high-performing firms. Journal of Management, 22(6), 889-908.

75. Moon, J. S., \& Choi, S. B. (2017). The impact of career management on organizational commitment and the mediating role of subjective career success: the case of Korean R\&D employees. Journal of Career Development, 44(3), 191-208.

76. Mowday, R. T., Steers, R. M., \& Porter, L. W. (1979). The measurement of organizational commitment. Journal of vocational behavior, 14(2), 224-247.

77. Murphy, K. R., \& Cleveland, J. N. (1995). Understanding performance appraisal: Social, organizational, and goal-based perspectives. Sage.

78. Nasution, F. N., Mariatin, E., \& Zahreni, S. (2018). The Influence of Career Development and Organizational Culture on Employee Performance. International Journal of Scientific Research and Management, 6(01).

79. Hong, E. N. C., Hao, L. Z., Kumar, R., Ramendran, C., \& Kadiresan, V. (2012). An effectiveness of human resource management practices on employee retention in institute of higher learning: A regression analysis. International journal of business research and management, 3(2), 60-79.

80. Nnabuife, E. K., \& Gilbert, F. A. Employee Training and Organizational Sustainability: A Study of Bayelsa State Broadcasting Corporation.

81. Nichol, L. M., Watson, J. C., Abernethy, R., Rechsteiner, E., \& Towers, J. (2015). Trends in the abundance and distribution of sea otters (Enhydra lutris) in British Columbia updated with 2013 survey results. Nanaimo, Canada: Fisheries and Oceans Canada.

82. Otuko, A. H., Chege, K., \& Douglas, M. (2013). Effect of training dimensions on employee's work performance: a case of mumias Sugar Company in Kakamega County. International Journal of Business and Management Invention, 2(9), 138-149.

83. Pallant, J., \& Manual, S. S. (2007). A step by step guide to data analysis using SPSS for windows. In SPSS Survival manual. Open University Press.

84. Pazy, A., \& Ganzach, Y. (2009). Pay contingency and the effects of perceived organizational and supervisor support on performance and commitment. Journal of management, 35(4), 1007-1025

85. Perreira, T. A., Morin, A. J., Hebert, M., Gillet, N., Houle, S. A., \& Berta, W. (2018). The short form of the Workplace Affective Commitment Multidimensional Questionnaire (WACMQ-S): A bifactor-ESEM approach among healthcare professionals. Journal of Vocational Behavior, 106, 62-83.

86. Perry, J. L., Engbers, T. A., Commentators, S. Y. J., Houston, D. J., Pandey, S. K., \& Risher, H. (2012). Back to the future? Performance-related pay, empirical research, and the perils of persistence. In Debating Public Administration (pp. 53-92). Routledge.

87. Pokharel, M. P., \& Ok Choi, S. (2015). Exploring the relationships between the learning organization and organizationa performance. Management Research Review, 38(2), 126-148.

88. Rahman, A., Shahzad, N., Mustafa, K., Khan, M. F., \& Qurashi, F. (2016). Effects of Organizational Justice on Organizationa Commitment. International Journal of Economics and Financial Issues, 6(3S).

89. Rashid, H. A., Asad, A., \& Ashraf, M. M. (2011). Factors persuading employee engagement and linkage of EE to personal \& organizational performance. Interdisciplinary Journal of Contemporary Research in Business, 3.

90. Ř́hová, Z. (2015). Influence of Organization Management on Systems of Performance Measurement and Management Control. Acta Informatica Pragensia, 4(1), 80-89.

91. Ringle, C. M., Wende, S., \& Will, A. (2005). SmartPLS 2.0 (M3) Beta.

92. Roberson, L., Kulik, C. T., \& Pepper, M. B. (2009). Individual and environmental factors influencing the use of transfer strategies after diversity training. Group \& Organization Management, 34(1), 67-89.

93. Rousseau, D. M. (1997). Organizational behavior in the new organizational era. Annual review of psychology, 48(1), 515-546.
94. Rouiller, J. Z., \& Goldstein, I. L. (1993). The relationship between organizational transfer climate and positive transfer of training. Human resource development quarterly, 4(4), 377-390.

95. Schuler, R. S., \& MacMillan, I. C. (1984). Gaining competitive advantage through human resource management practices. Human Resource Management, 23(3), 241-255.

96. Schuler, R. S., \& Jackson, S. E. (2005). A quarter-century review of human resource management in the US: The growth in importance of the international perspective. Management revue, 11-35.

97. Selvarajan, T. T., Singh, B., \& Solansky, S. (2018). Performance appraisal fairness, leader member exchange and motivation to improve performance: A study of US and Mexican employees. Journal of Business Research, 85, 142-154.

98. Shahid, A., \& Azhar, S. M. (2013). Gaining employee commitment: Linking to organizational effectiveness. Journal of Management Research, 5(1), 250.

99. Shen, J., \& Tang, C. (2018). How does training improve customer service quality? The roles of transfer of training and job satisfaction. European Management Journal.

100. Swanson, R. A. (1995). Human resource development: Performance is the key. Human Resource Development Quarterly, 6(2), 207- 213.

101. Thomas, S. L., \& Bretz Jr, R. D. (1994). Research and practice in performance appraisal: Evaluating employee performance in America's largest companies. SAM Advanced Management Journal, 59(2), 28

102. Vashishtha, S. (2016). Employee Engagement, Training and Career Development (Tata Tele Services Limited â€"A Case Study). Journal of Commerce and Trade, 11(1), 101-108.

103. Vidal-Salazar, M. D., Hurtado-Torres, N. E., \& Matías-Reche, F. (2012). Training as a generator of employee capabilities. The international journal of human resource management,23(13), 2680-2697.

104. Wang, G., \& Singh, P. (2014). The evolution of CEO compensation over the organizational life cycle: A contingency explanation. Human Resource Management Review, 24(2), 144-159.

105. Weng, Q., McElroy, J. C., Morrow, P. C., \& Liu, R. (2010). The relationship between career growth and organizational commitment. Journal of Vocational Behavior, 77(3), 391-400.

106. Yucel, I., McMillan, A., \& Richard, O. C. (2014). Does CEO transformational leadership influence top executive normative commitment? Journal of Business Research, 67(6), 1170-1177.

\section{AUTHORS PROFILE}

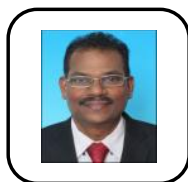

First Author Mr. Gopal Perumal is a Senior Lecturer at Faculty of Business, Accounting and Management, SEGi University, Kota Damansara. He has 20 years of experience in corporate sector and 15 years of experience in academia. His expertise is in the areas of finance, investment and business management. He has taugh various subjects including finance, investment, banking and business management. He has published numerous papers in peer reviewed international journals as to date. Mr.Gopal holds a Master degree in applied finance and investment and Bachelor's degree in business administration. $\mathrm{He}$ is currently pursuing his $\mathrm{PhD}$ in management. In a professional attachment, he is a Life Member of Malaysia Finance Association and Member of Malaysian Institute of Management.

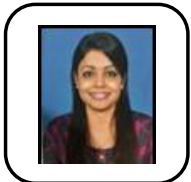

Second Author Ms. Suguna Sinniah is a Senior Lecturer at Faculty of Business, Accounting and Management, SEGi University, Kota Damansara. She has 13 years of experience in cooperate and academia. Her expertise is in the areas of human resource management, organizational behavior and international business. She has taught various subjects such as strategic management, organizationa behavior, entrepreneurship, international business, business ethics and human resource management. She has published numerous papers in peer reviewed international journals as to date. Ms.Suguna holds a Master degree in Human Resource Management and Bachelor's degree in Business Administration. She is currently pursuing her $\mathrm{PhD}$ studies. 


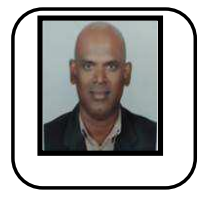

Third Author Mr. Ilangovan Perumal is a Senior Lecturer Faculty of Business, Accounting and Management, Segi University, Kota Damansara. His expertise is in the areas of management information systems, ecommerce, computer science educational systems and IT in business. He has taught various computer related subjects for various background of students, locally and internationally ranging from certificate to undergraduate level. He has published few papers in the various computer and business related journals. Mr. Ilangovan Perumal holds a Master degree in Computer Science from University of Malaya and currently pursuing Phd in IT.

Forth Author Dr. Zafir Khan bin Mohamed Makhbul

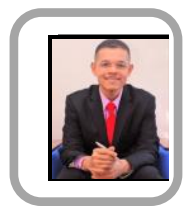
is a Professor at School of Management, Faculty of Economics and Management, University Kebangsaan Malaysia. He has over 20 years of teaching and research experience with Universiti Kebangsaan Malaysia (UKM). $\mathrm{He}$ obtained his Bachelor of Business Administration from University Utara Malaysia, Master of Business Administration from University Kebangsaan Malaysia and Ph.D in Management from University Technology Malaysia. He spent over 20 years of researching, writing and lecturing on the theme "Organizational Management and Human Resource Management" in Malaysia. His books have become major and supplement references in Public and Private Higher Learning Institutions and Colleges. His recognitions of expertise/academic and industrial experience have been proven through the appointments as Program External Examiners, Member Board of Studies, Board of Moderators, Academic/ Course Advisor and Technical Committee for National and International Conferences. Amongst his best achievements are National Book Award 2017 for the Category of Best Entrepreneurial Book, Gold Medal Award in IIDEX 2017, Silver Medal Award in IIDEX 2016; Certificate of Appreciation for Outstanding Effort in Writing Organizational Management by McGraw-Hill Education (Asia) 2008.

Fifth Author Dr. Ramesh Kumar currently is an Assistant professor for the Faculty of Business \& Finance, University Tunku Abdul Rahman (UTAR) Malaysia. He received his Master's degree in MBA from the University of Utara Malaysia (UUM). Graduate with B.Mgmt, (Hons) Major in Management and Minor in Political Science from the Universiti Sains Malaysia. He pursued his Ph.D. from USM in Human Resource Management field. He has more than 12 years of progressive Human Resource Executives experience and 12 years of teaching experience. 